\title{
Varieties of agencies during working life changes
}

\section{Anu Järvensivu}

University of Jyväskylä, University of Vaasa, Tampere University, Humak University of Applied Sciences, Finland (anu.jarvensivu@humak.fi)

\begin{abstract}
The aim of this study is to shed light on the varieties of workers' agencies in working life change situations, which is an under-researched topic in the literature of workplace learning and in working life studies. The research questions are what kinds of agencies there are to be found when workers encounter changes and how the different kinds of agencies are connected together. The understanding of agency is grounded on the subject-centered socio-cultural approach, whereas the methodological approach is based on applying life-course perspective on research material consisting of 48 working life narratives written by Finnish adults. The narratives are analyzed by abductive content analysis. The results reveal the dynamical and periodical processes between the different kinds of agencies during one's working life narrative. The different forms of agency overlap and rotate. Suffering can be seen as a dynamic concept mediating transformative agencies, small agency and resistance.
\end{abstract}

Keywords: Agency; small agency; suffering; working life changes

\section{Changing working life calls for individual agency}

The working life of future is expected to be quite different from the models and logics we are used to. One aspect of that is the growing number of different kind of changes during one's work career. However, many features of the future are already here making the anticipation possible. (Gratton, 2011) The new features of work have encouraged particularly labor economists to produce several models for anticipations especially concerning the technical development and automation of human work. The most 
fundamental debate is characterized by a dichotomy between the view that automation will spell the end of human work and the argument that technologies will increase the demand for labor like they have done in the past (Acemoglu \& Restrepo, 2018). Even the "moderate" forecasts have suggested (massive) disappearance of whole occupations or at least tasks, which means remarkable needs for reflection, training and new choices and starts for working adults (Frey \& Osborne, 2013; Nedelkoska \& Quintini, 2018; World Economic Forum, 2018.)

Acemoglu and Restrepo (2018) have stated that the correct approach to changes in labour market would be task-based, not occupation-based, which means that there will be more changes in the working peoples' tasks and duties than in the whole occupation structure of the society. The researchers have constructed a task-based economic framework, where automation is conceptualized as replacing labor in specific tasks. They argue, for example, that the displacement effect of automation is balanced by the creation of new tasks in which human labor has a comparative advantage, which for its part fosters a countervailing reinstatement effect for labor. Nevertheless, Acemoglu and Restrepo (2018) anticipate that the adjustment process is likely to be slower and more painful than this account of balance between automation and new tasks at first suggests. This is because the reallocation of labor (meaning adult people, for the most) from its existing jobs and tasks to new ones is a slow process, in part owing to time-consuming search and other "labor market imperfections". (Acemoglu \& Restrepo, 2018.)

The approaches, conceptions and terminology used by the labor economists highlights structure over human agency. However, it is obvious that the working life changes require a remarkable amount of agency and learning to become a living reality. In addition, even the economists state that it is worth to note that new tasks require new skills and competencies, and especially when the education sector does not keep up with the demand for new skills, a mismatch between skills and technologies will complicate the adjustment process (Acemoglu \& Restrepo, 2018). For these reasons, understanding working life changes is a crucial necessity to the education and learning researchers and practitioners. There certainly will be a need for lifelong education and learning and some education system reforms, too. However, for the most, there is and will be an individual level need for continuing reflection and agency in the changing situations confronted during one's career and life course. In their profound literature review, Eteläpelto, Vähäsantanen, Hökkä and Paloniemi (2013) have stated that widening the theoretical perspective of workplace learning into subject's active participation and agency at work is needed in order to realize workers' commitment to the ideal of being a flexible and creative life-long learner and an active co-developer of working practices.

In this article, the individual agency manifested in working life change situations, especially in organizational changes, is elaborated based on empirical qualitative study. I ask what kind of agencies there is to be found when people encounter changes at their workplaces and how they are connected to each other. Especially, I am interested in "small or minimal agency" (Honkasalo, 2008) that has not been in the focus of working life or workplace learning research. I propose that there exists varieties of interconnected individual agencies behind the aforementioned labor market imperfections that are worth recognizing both at the firm level development processes and at the society level. At the individual level, the agency is conditioned by sufferings generated by working life changes that cause many kind of experiences of losses to working people. A better understanding of these experiences and interconnected varieties of agencies would be crucial to experts who offer counselling, training or education to adult people in changing working life. 


\section{Variations of agency in change situations}

Agency in organizations and working life is characteristically understood as a transformative power, as something needed to generate (positive) development. Tuominen and Lehtonen (2018) state that in organization studies the concept of agency is used to explain organizational members' ability to purposively pursue continuity or transformation in their social contexts. They use the notion of transformative agency in order to refer to the individual's ability to purposefully transform the structures in which they are embedded. The researchers state, that the kind of agency has been widely considered as actions of individuals or groups of similarly positioned individuals who compete with other agents in advancing their interests. In contrast to that, Tuominen and Lehtonen (2018) want to see agency as a multilevel phenomenon, which is relationally and dynamically constituted in organizations.

The dynamic nature of different kind of agencies at workplaces has already been noticed in the classic sociological research literature based on labor process theory (Braverman, 1974) that has taken on the foreground the resistance and consent of the workers (Burawoy 1979, 1985; Edwards 1979; Friedman, 1979). By using these approaches, even the silent resistance to development projects and other activities not hoped for, namely organizational misbehavior has been analyzed (Ackroyd, 2013; Järvensivu, 2007). Respectively, it has been shown that sometimes learning at work can be seen as the employers' means of intensifying and controlling work, but that it can be opposed and resisted by workers, too (Järvensivu \& Koski, 2012).

During the years, the recognition of the range of recipient responses to change has been expanded beyond resistance per se to include cynism, withdrawal behaviors, readiness, support and commitment (Boram, 2018). Rafferty and Jimmieson (2017) remind that the approaches to resistance to change in research literature differ, but the recent thinking suggests that resistance is a multidimensional construct.

Despite the findings in social sciences, Boram (2018) states that in recent organizational and management literature the change recipients are described as implicitly if not explicitly passive in all the characterizations used and the agency of them has not been of much interest. Instead, it has been common to concentrate on the role of the change agents in organizational changes. He sees that even the term resistance has been later conceptualized and operationalized as a reactive passive attitude, although it was originally used to describe the active application of a force to counter change. Boram states that the distinction between positive (acceptance) and negative (resistance) responses to change and the tendency to ignore the degree of activation involved in recipients' responses fails to capture a meaningful component of recipients' responses to change (Boram, 2018). Respectively, Harman (2014) states that the terms learning and learner are often used generically in the research literature of workplace learning, as if they had a fixed and shared meaning and the approach to workplace learning all too often is alignment with the targets and development needs set by management, whereas workplace learning also could introduce resistance (Harman, 2014).

Rafferty and Jimmieson (2017) state, that there is plenty of critical research about the negative influences of organizational changes on the well-being at work but the subjective perceptions of the change situations are less studied. They propose that this focus on objective measures may still have resulted in an underestimation of the effects of organizational change on employee well-being. They emphasize the importance of researching the individual sense making processes in order to understand workers experiences and reactions to organizational changes. (Rafferty \& Jimmieson, 2017). Tuominen and Lehtonen (2018) remind that two central properties underlying working 
life agency, namely reflexity and bargaining power differ. The bargaining power is more explicitly tied to the structure, while reflexity can be seen as a more durable and less conditioned by structure. According to them, more research is required to understand how the properties needed to identify the opportunities to change emerge and interact to create individual's transformative agency in different organizational contexts. (Tuominen \& Lehtonen, 2018).

These debates show, that after all the years of working life research, there still seems to exists under-researched aspects concerning the agency of workers in organizational changes and in other working life change situations. A better understanding of these aspects would be essential to be able to facilitate changes and to help and counsel workers to construct their professional identities and work careers. Based on the aforementioned studies, the research gaps seem to situate in the workers active meaning making processes that create different kind of agencies and understanding the varieties of agencies and degrees of activity involved in the workers responses to changes. In line with these research needs, the study at hand concentrates on the different kind of workers' agencies when they encounter change situations (mostly organizational changes) at their workplaces.

My understanding of agency is based on subject-centered socio-cultural approach proposed by Eteläpelto and her colleagues (2013). I agree with them in that there is a need to understand subjects in their complex socio-cultural surroundings and to investigate them from a life-long perspective, not merely from a momentary and cross-sectional point of view. The subject-centered life course agency sees adult learners and workers as individuals who not only learn the new knowledge and skills needed, but also act as feeling and willing subjects. These kind of subjects actively prioritize, choose and consider what is worth aspiring in their life and in the future. The researchers state that the aspect of life-course perspective has been neglected in theories and studies of workplace learning. (Eteläpelto et al., 2013).

I apply in my research the life-long or life-course perspective by studying retrospective working life narratives written by 48 Finnish adults using the perspective of changing forms of agency. Because I am interested in the varieties of agencies in working life change situations, I concentrate on the parts of the narratives that describe the changes and the writers' experiences of them. Resulted from that, the life-course perspective is restricted and focused to 3-40 years of the writers' lives.

Respectively, my interest in varieties of agency is focused on the socio-cultural context of my study, which is the workplaces and the changing working life in Finland. As can be noticed in the literature cited above, in the context of working life, it has been conventional and justifiable to make a separation between transformative agency in line with the development targets of the management (like participating in the firms' development work) and workers' resistance. Based on the individualization tendencies of working life and the noticed need to focus on individual subjects perspective (Eteläpelto et al., 2013), I also differentiate between the in-firm transformative agency and transformative agency in respect to one's career (like career transitions).

In the light of my research material, the Finnish working life narratives, there still exists one further need to an extension of the understanding of workers' agencies in change situations. I propose that in order to be able to shed more light on the questions about workers' agency in working life changes, there is a need to take one extremely typical reaction or response of the workers under consideration and that is what I am going to do next. 


\section{Small agency and enduring suffering in change situations}

Undoubtedly, workers transformative agency and their active reactions, responses and resistance to changes in all of their forms are central varieties of agency in working life change situations. However, none of the cited approaches to agency in working life changes recognizes the kind of agency that Honkasalo $(2008,2009)$ refers to by using the term "small agency". She uses the concept to describe the agency that contrasts to the notion of rational agency, aimed at social transformations (Honkasalo, 2009). According to Honkasalo (2008), the widely applied rational and goal-oriented notion of human action and agency is too narrow a notion to allow the precarious modalities to be captured.

Honkasalo has developed the notion of small agency in her anthropological study of Finnish North Karelia, the region worldwide known for its' heart diseases. Honkasalo did her research among the people who have remained in North Karelia after structural changes that have caused most young people to move to other parts of the country. The people, especially women, described the life as tight or restricted ("ahas") compared to full or rich life that they formerly had and that was taken away from them. They had gone through many kinds of losses, for example, the family members had moved away and their work and profession (agriculture) had become almost impossible. Honkasalo states that the women suffered a lot because of the situation, but also acted while suffering. The everyday life of them was filled with a modality of agency that aimed neither at social transformation nor at resistance. The ends of their agency were to keep one's own and the family's "hold on the world", and to reconstitute meaningful kinship, residence and identity. (Honkasalo, 2009).

These descriptions have much in common with the experiences and descriptions of Finnish people in working life and organizational change situations that I have studied in my previous studies using the narrative material at hand and other research materials before that (Järvensivu, 2014, 2016). With regard to the narrative material, there were plenty of losses, which the writers described. The writers told how they had lost their working communities, colleagues, their tasks, duties, and even their work identities in the organizational changes. They felt being left alone and alienated, even oppressed. The workers certainly suffered. They cried. They had severe sleeping problems and many kinds of symptoms. They got illnesses and diagnoses (Järvensivu, 2016). In the light of these findings, the agency in working life change situations is embedded in tough experiences and suffering corresponding the experienced socio-cultural context in North Karelia.

Frost and Hoggett (2008) have used Pierre Bourdieu's conceptualization of social suffering as a notion that draws attention to social misery both as an unequal distribution of material goods and as people's lived experience of domination and repression, including feelings (humiliation, anger, despair and resentment). They state, that the notion of suffering denotes the intermeshed components of thinking, feeling, responding, and acting. In their psychosocial approach, they also have been concerned with suffering as both a reflexive and non-reflexive phenomenon. In other words, social suffering can at times be thought about, critically and creatively, but at times, it is embodied, enacted or projected because it cannot be thought about. Social suffering draws attention to the lived experience of inhabiting social structures of oppression, and the pain that arises from this. (Frost \& Hoggett, 2008).

According to Renault (2010) the current phase of capitalism, labelled neoliberalism, is characterized by the emergence of new conditions of work as well as structural trend toward social exclusion. The subjective difficulties that these new conditions of work produce can be labelled as suffering at work, which has a double implication for social 
critique. Suffering at work is a part of pathological aspects in the new working conditions, but it also produces individualization and guilt complexes that are obstacles to any practical dynamic of social transformation (Renault, 2010).

In her study, Honkasalo (2009) defines social suffering as an umbrella category that connects different kinds of human problems, including those that create pain, distress, and other trials that people undergo or are forced to endure. She uses the notion of social suffering as a methodological tool for thinking about illness experience, uncertainty, and agency (Honkasalo, 2009). She sees suffering as an intersubjective experience, but she also follows Bourdieu and focuses on sufferings in plural form. She is interested in the tiny, small-scale sufferings, which are produced within and by the social processes of everyday life. She has found variety of peoples' attempts not to render themselves as objects of circumstances, but instead to act. Sometimes these people fought to try to keep suffering at distance. However, she sees that people somehow "embraced contingency" and didn't try to avoid it. Honkasalo states that people in North Karelia didn't suffer for uncertainty. Instead, they were in constant danger of losing their grip of the world, their presence. (Honkasalo, 2009).

Honkasalo defines presence following Ernesto Martino as one's ability to be an active agent in the world. She sees that protecting one's being in the world or fighting for having the possibility to remain there constitutes a cultural core of human agency. The loss of one's own subjectivity, of one's ability to act can be threatened for many reasons, but Honkasalo reminds that the cultural context bears many meaningful modes of holding on to a world and having a grip on it within social interactions. Honkasalo follows Martino's thinking on agency as having a grip on the world. That way, she comes to the approach of the small agency that makes a clear difference to the agency considered as intentional, individual, rational, and normative and aiming at social change. (Honkasalo, 2009). I propose that the kind of understanding of agency and its' connections to (social) suffering is extremely important to be able to understand the agencies of my research participants.

Honkasalo reminds that the agency should be explored within the grammar of concepts within which it resides, which means that in the context of social suffering, the notion of agency embraces ethical aspects as well (Honkasalo, 2008). Enduring suffering was shared and valued among the North Karelian women. Enduring created ethical agency and the identity that was considered a proper North Karelian woman. It was an investment, struggle and achievement. The agency was crucial to endure suffering (Honkasalo, 2009).

Enduring suffering can be seen as an agency along with the lines of the theological etymology and roots of suffering (passion). Regarding theological heritage, suffering as an experience is considered as carrying along the experience of rendering oneself more or less passive, adapting. However, Honkasalo (2008) reminds of the often-neglected domain of agency that human experience always entails. In addition to attempts to control uncertainty, it also can be encountered by embracing it, living with it, bearing it (Honkasalo, 2008).

In this study, I am especially interested in the possibility to find small (ethical) agency in the narratives of (mostly women) workers who had encountered change situations at their workplaces. Would it be essential to raise the small agency, like enduring suffering, to the categories of relevant forms of agency beside the transformative agency and resistance in working life studies? 


\section{Methodology}

This research is based on written stories, that I call working life narratives, collected in a research project at Tampere University. The narratives were collected by writing invitation that was focused at Finnish adults during the years 2011-2012. In the invitation, we asked people to write us about the solutions they have made to get through the working life changes that they had encountered. We also encouraged people to tell us about the "minor and major victories at the working life field", because we wanted to collect happy narratives, too.

The invitation was disseminated through newspapers, magazines and social media. Forty-eight people sent us their working life narratives. Most writers were women and only a few were under forty years old. Some of the stories were short but most consisted of several pages and consisted the whole working life narrative of the writer. We also got a couple of "books" the length of which were tens of pages. Some of the stories were written by hand and difficult to read. The research material was quite extensive and versatile. It has been very laborious to analyze, partly resulting from the tough experiences described in the stories, too. In the end, there were not so many happy narratives. Because of its very personal nature, the material is not made open.

During the past six years, I have read the stories many times and made different kind of analysis of the material using, for the most, narrative approaches (Hyvärinen, Hatavara \& Hydén, 2013). For example, the typical narrative of working life changes, happy and unlucky narratives and the episodes and traits of them have been differentiated. In that sub-research, it was found that almost every story started at the situation of organizational change and that there were plenty of common experiences including losses, loneliness, illnesses and sufferings. These results have been published in a scientific book written in Finnish (Järvensivu, 2014).

The other narrative study has been made about the embodied social suffering that turns to illnesses and further to survival narratives by which the domination, oppression and social suffering is resisted. That sub-research showed the importance of the notion of social suffering in understanding the writers' reactions and feelings and the structural oppression behind them, which is used as an important background information for the study at hand. Six remedial narratives were revealed in that study. Using them, the writers changed their narratives from unlucky or even suffering narratives to happy narratives. These results have been published in a social medical scientific journal in Finnish (Järvensivu, 2016).

In this article, I continue based on the fore mentioned analyses and focus on the perspective of agency in change situations, which has not been previously analyzed. My objective is to find out the varieties of agencies and the possible connections between them. Especially, I concentrate on the small agency. I apply abductive content analysis meaning that I move back and forth between inductive (data-driven) and deductive (concept- or theory-driven) approaches to the research material. (Graneheim, Lindgren \& Lundman, 2017). First, I make a categorization of the different forms of workers' agencies manifested in organizational and other working life change situations. That part of the study is merely descriptive (Graneheim et al., 2017). Then I deepen the interpretation and concentrate on two narratives to be able to answer the questions concerning the nature of the small agency and the connections between different kind of agencies during the narrative. That second part of my analysis is based on an interpretive paradigm (Graneheim et al., 2017). 
I have marked the citations by numbers of the writings. The translations from Finnish are mine and I am aware of that I might have lost some nuances that would be important to the interpretation. I also have anonymized some expressions of the citations.

\section{Results}

\section{Workers transformative agency, resistance and small agency in change situations}

While the first research task is to investigate the variety of the workers' agencies in organizational and working life change situations, the convenient analysis unit of the study is the expression of agency. It has been found that the presence of expressions of agency vary between people's narratives, and even profiles of identities according to the presence of expressions of agency and learning can be formed based on that (Biasin \& Evans, 2019). Concentrating on the expressions found in the complete narrative research material at hand allows finding out the variety of agency expressions. The analysis of the different kind of agencies proceeded as follows: First, I picked up the different kind of expressions of workers agency from the research material. Then I categorized them into subcategories. Finally, I reduced the subcategories to main categories.

I formed and named the main categories using the theoretical considerations presented in the theoretical part of this article. The main categories I found are (in-firm and during career) transformative agency, resistance and small agency. The subcategories of the transformative agency are participating in development processes (in-firm transformative agency), education and training (in-firm or in-career transformative agency) and career transitions, like taking a new job, learning a new vocation or profession or starting as an entrepreneur (transformative agency during career). The subcategories of the resistance are complaining to the supervisor about the work content, trying to negotiate about the workload and asking for more compensation for extra work. Finally, I differentiated small agency as having some (minimal) influence on one's own job, enduring suffering, balancing between being present and taking distance and getting illnesses. I give some examples of the categorization and reduction process in the table below.

\begin{tabular}{|c|c|c|}
\hline Examples of the expressions of agency & $\begin{array}{l}\text { Subcategories of } \\
\text { agencies }\end{array}$ & $\begin{array}{l}\text { Main categories } \\
\text { of agencies }\end{array}$ \\
\hline $\begin{array}{l}\text { "After two years I had my strength back } \\
\text { and I started to think about a break. Even } \\
\text { leaving the job didn't seem to me like } \\
\text { escaping anymore. I took a leave for } \\
\text { training myself." (case 10) "I got a new } \\
\text { job. Now I have been in the new job a } \\
\text { couple of months and I am very happy and } \\
\text { enjoy my work." (case 3) } \\
\text { "I left the senseless paid work and started } \\
\text { my own business. I still work a lot but I } \\
\text { can control it myself and do the things I } \\
\text { want to." (case 28) }\end{array}$ & $\begin{array}{l}\text { Participating in } \\
\text { development work } \\
\text { Educating } \\
\text { Training } \\
\text { Career transition } \\
\text { (new job, new } \\
\text { vocation, starting } \\
\text { as an entrepreneur) }\end{array}$ & $\begin{array}{l}\text { Transformative } \\
\text { agency } \\
-\quad \text { in-firm agency } \\
-\quad \text { in-career } \\
\quad \text { agency }\end{array}$ \\
\hline
\end{tabular}




\begin{tabular}{|c|c|c|}
\hline $\begin{array}{l}\text { "I told to my supervisor that I couldn't } \\
\text { handle the work load even if I wouldn't be } \\
\text { a part-timer." (case } 3 \text { ) }\end{array}$ & $\begin{array}{l}\text { Complaining of } \\
\text { the work content } \\
\text { or workload } \\
\text { Asking for more } \\
\text { compensation for } \\
\text { extra work }\end{array}$ & Resistance \\
\hline $\begin{array}{l}\text { "We will have a fusion. I was committed to } \\
\text { my unit but now I have to freeze my hearth } \\
\text { in order to get the job done. You have to } \\
\text { zombie out not to go with the negative } \\
\text { discussions in coffee room. I have decided } \\
\text { to work at home. I feel like deserter, but I } \\
\text { don't have enough strength to fight with } \\
\text { them anymore. It has been interesting to } \\
\text { notice the absent-minded sickness in } \\
\text { myself that I can't abolish by explaining." } \\
\text { (case } 7 \text { ) } \\
\text { "I started to get symptoms, because I had } \\
\text { no social affiliation. If you complain, the } \\
\text { spiral is there. You will be stigmatized and } \\
\text { repressed. I felt that I had been excluded of } \\
\text { my own unit." (case } 42 \text { ) } \\
\text { "I got some kind of crisis, and had physical } \\
\text { sicknesses." (case 15) }\end{array}$ & $\begin{array}{l}\text { Enduring suffering } \\
\text { Balancing being } \\
\text { present and taking } \\
\text { distance } \\
\text { Getting illnesses } \\
\text { Having some } \\
\text { influence on one's } \\
\text { own job }\end{array}$ & Small agency \\
\hline
\end{tabular}

Table 1. The analyzing and categorization of the agency in change situations.

Because of my interest in the under-researched small agency and its' role and function in the working life change situations, I analyzed further the narratives where there were expressions of small agency, suffering and enduring.

\section{Enduring suffering as a form of small ethical agency in change situations}

In order to give an answer to the research questions of the connections between the varieties of the agencies and the role and nature of the small agency during the working life narratives I picked up two stories to a scrutiny. I chose the narratives that included profound descriptions of the experiences and varieties of agencies and gave some hints of the time perspective, too.

The most prominent cases were the narratives of one teacher and one librarian who later changed her job as a union officer. Both of them were middle-aged women who had a university degree. The story of the librarian was one of the narratives that included almost all the parts or episodes of the typical narrative of working life changes, which were found in my previous study (Järvensivu, 2014). The parts were organizational changes, losses, breaking the communities, heavy workload, chaos, suffering, loneliness and alienation, stigmatized as a poor worker, illnesses and break. The only missing part was the break that was an important episode in many other stories, including the story of 
the teacher. The break in a story could be a sickness leave or alteration leave or a leave for education and training or an unemployment after a dismissal. The function of the break to the writers' narrative was resting and reflecting, which for its' part, could transform the unhappy narrative to happy one (Järvensivu, 2014).

I'1l start by analyzing the excerpt of the teachers' story. The excerpts from the working life narratives are limited to the descriptions of working life change situations, which means that the analysis concentrates in these two cases on about 4 and 20 years period of the writers' life course. I have marked in capital letters my interpretations to make it easier to follow my analysis.

\begin{abstract}
Year after year I wanted away. I tried to think about other opportunities. Two years I was so tired that I could not think about them properly or apply for opportunities. (SUFFERING, NO STRENGTH FOR TRANSFORMATIVE AGENCY) I just wanted away. Away. (WANT TO DISTANCE) I had difficulties with my boss. When I promoted the interests of my colleagues or students in the meetings, I got a reputation of a challenging person. (RESISTANCE) My supervisor counselled me many times how I should behave and once he asked directly, why I am so difficult. (NOT A GOOD WORKER) When I got my strength back after two years I started to think of a break. After one year, I was strong enough to make a decision. Leaving the workplace didn't feel like escaping, anymore. (NO MORE ENDURING OR ETHICAL NEED TO STAY; DISTANCE) I started the training leave. (BREAK; TRANSFORMATION) After the year, I came back but to other kind of tasks, fortunately. I have managed the situation only by thinking that this is temporary (ENDURING, TEMPORARILY). I have suffered sleeping difficulties and illnesses. (SUFFERING, GETTING ILLNESSES) I apply for other jobs all the time. (TRANSFORMATION) (case 10)
\end{abstract}

As the example of the teacher's narrative shows, the varieties of agencies have dynamical connections and changing nature when inspected in life-long perspective (in this case meaning a couple of years). Transformative agency, resistance, suffering and enduring overlap, shift, and change during the working life narrative. Suffering takes more place when the space for agency becomes narrow. The teacher endures suffering for a while, but there exists resistance and considerations of transformative agency at the same time. It seems that during the years, transformative agency begins to displace enduring in the teachers' case but that is a very slow process. At the writing moment, suffering still stays, but the time horizon gives hope. Enduring suffering is interpreted to be temporary, which makes it durable (see also Honkasalo, 2009).

In the teachers' story, enduring suffering and staying at one's place seem to be culturally appreciated, whereas leaving the working community is seen as a betrayal or escaping. In the same way, Honkasalo (2008) stated that staying and being present were important dimensions of enduring and ethical agency in North Karelia, where responsibility defined agency from the viewpoint of a tension between choice and commitment. In line with that in the working life narratives, enduring suffering also enables being present, which could be interpreted as not losing one's subjectivity (Honkasalo, 2008). The agency is small, staying at one's place, mostly silent (Järvensivu, 2016), because it is valued. It is something that good workers would do. However, this kind of subjectivity, agency, have to be interpreted as local, in-firm agency. Enduring suffering at one's workplace means retaining one's presence and potential agency at that workplace. It means commitment to the workplace and working community. At the same time, enduring suffering means choosing not to leave, whereas leaving would have meant transformative agency in perspective of one's career. For the most, enduring also means not to choose resistance, either. 
Enduring suffering was choosing to stay and choosing enduring meant suffering. The teacher tried to find a balance between staying present and taking distance. She wanted away, but the ethical responsibility to work community forced to stay. It took an enormous strength to leave the workplace and the community and there was a need for suffering for years before the teacher had enough strength and 'leaving the workplace didn't feel like escaping, anymore' (case 10).

\section{Suffering as mediating the different kinds of agencies}

The second narrative, the story of the librarian, has common features to the story of the teacher, but there exists different aspects, too. In the text below I cite an excerpt of the librarian's story.

I am a woman, over fifty years old. My first long employment relationship started during the years at the university. I worked as a librarian and when I got my degree, I thought that, why not. Therefore, I qualified for that, got the permanent job as a librarian, and enjoyed my work. In the library, I also experienced managerial job, bureaucracy, the positions of the employee and the employer and the difficulties of the development work. (TRANSFORMATIVE AGENCY) I was social. I worked for the labor union and was the voice for the employees. (TRANSFORMATIVE AGENCY INCLUDING RESISTANCE) That was interesting and I learned a lot. I got promotions and many kind of tasks during my library career.

The library work has changed enormously from the 1980's. I had the chance to see the time of the pencils and papers and so I saw the fast technical development. All these CD-roms, awkward online modems and then the Finnish and international databases, automation, web 2.0 and who knows all this metadata and digitalization of today. The speed of the work began to be dizzy in 1990's. It was addictive and stressful for someone who has a strong work orientation. (TRANSFORMATIVE AGENCY) In the beginning of the 1990's I was a supervisor and within many kinds of projects and working committees. Every day was different. My work was interesting and fun. The working community was nice, my subordinates supported me, and the supervisors encouraged.

But then. What happened? I was no more with the union work because I worked as a supervisor. (NO MORE RESISTANCE) The routine work, planning, purchasing. (NO MORE TRANSFORMATIVE AGENCY) My nearest supervisor started to get part-time pension benefits. I noticed that I worked for 1,5 persons. I asked for more salary but didn't get any. (RESISTANCE) I felt to be between a rock and hard place in the committees, in which I sat. I know how my subordinates wanted to work and what kind of changes they wanted. The directors wanted something else. (TIGHT AND NARROW SPACE) I had to take care of some unpleasant jobs as a supervisor. The fluent flow of work was my main objective and there you have to do against individuals, unfortunately. You can't please everyone. (GOOD WORKER / SUPERVISOR?) I felt that there was a great contradiction between the objectives of my own work and the objectives of the library. This change could be seen everywhere in the library work. (MORAL CONTRADICTION) There were contradictory changes in the economic principles. (SOCIAL SUFFERING)

The others showed symptoms, too. The supervisor is responsible all the time and she has to be ready for everything. I had never thought that I would cry because of work but one day I did. (SUFFERING) I cried for anger and for powerlessness. I was only one mechanical part of the large apparat. I couldn't keep my direction. (LOSING ONE'S PRESENCE AND AGENCY) I had to adapt to the direction of the library's managers, although I knew that it would cause suffering in the personnel. (NOT A GOOD WORKER / SUPERVISOR) I was ever more frustrated. I noticed that Fridays, after the kids had gone to bed, I sat at the kitchen table with a bottle of wine and a candle. I was wondering what I would do with my 
life. (TRANSFORMATION?) I knew that I would have a career in the library. I would get an opportunity to influence on the library inside it, if only I would be patient. They liked me at the upper floor although I was critical. (TEMPORARY ENDURING FOR THE BECOMING POSSIBILITY ON TRANSFORMATIVE AGENCY)

I was almost forty, then. I got some kind of crisis, and had physical illnesses. (SUFFERING, GETTING ILLNESSES) I started to think that if I didn't leave the library now I would stay there and wait for the retirement. (ENDLESS ENDURING) I felt that I was absorbed empty. (SOCIAL SUFFERING) I didn't want to develop the library to the direction it was taken by the management. I do not know, maybe I thought too much about myself and about my career in the library. (OVERESTIMATING TRANSFORMATIVE POSSIBILITIES?) However, I felt that I was filled with the kind of things that functioned like the filling in the ragdoll. I was becoming rigid and inflexible and I couldn't move the things around me. (SOCIAL SUFFERING, LOSING ONE'S AGENCY) My colleagues saw me suffering and they tried to help and support, but in the end, I was alone in the committees and negotiations. (LONELINESS, ALIENATION) Just then, my own union was recruiting an officer. I felt that it was for me. I made an application. There were 62 applicants and I won. (TRANSFORMATIVE AGENCY) First, there were quite peaceful working conditions, but then the changes began there, too.

How did I survive? I have seen so much that I know that I am safe if I do what I am asked to do. (NOT LOSING ONE'S PRESENCE) No more. (NO RESISTANCE, NO IN-FIRM TRANSFORMATIVE AGENCY) I am not high-flying for the quality of my job, anymore. They respect me and I have some influence on my job. (SMALL AGENCY) I have learned my lesson. It is a consequence of the exhaustion, which I suffer, too. Resting doesn't help for that. It is not only physical fatigue in its nature. It is in my soul. Sometimes thinking about it makes me feel sad, but on the other hand selfishness and self-preservation tell me that it must be that way, otherwise you don't survive. (SOCIAL SUFFERING, ENDURING) (case 15)

In the librarians' story, enduring suffering and not leaving the library might have meant possibilities to retain one's presence and even have possibilities to transformative agency in the future. There was a promise that enduring suffering would someday change to infirm transformative agency. However, the situation was too tight, space for agency too narrow, possibilities too uncertain and social suffering too much to endure for the librarian. She was about to lose her hope for better, her presence and even her small agency, but then became the possibility to transformative agency at the level of her career.

After all, the end of the story has different features. The changes have begun at the new workplace, too. It seems like the woman had lost her endeavors to in-firm transformative agency. She is suffering again and she is exhausted. It could be interpreted that the woman suffers for having lost something about her agency, the transformative part of it. Now she tries to endure and hang up with the small agency she has in the form of influence in her own work, although she is longing for the transformative agency that she once had.

Suffering is in the narratives connected to another form of small agency, too, which likewise is a part of the teachers' and librarians' stories. Many writers described different kind of symptoms, sicknesses and illnesses. Most of them were mental in nature, like depression or burnout. These illnesses could be interpreted as forms of suffering, but they also contained space for one special kind of agency. That was an agency of the victim (Wainwright \& Calnan, 2002). The illnesses and diagnoses made it possible to the worker to be confessed as a good and proper worker who had been the victim of the ever hardening working life and who despite of that had worked a lot, actually too much. In addition, illnesses could be cured (Järvensivu, 2016). That opened up possibilities to transformative agency. 
The role of suffering seems important in understanding the workers' agencies when they encounter change situations. My first perception is that, when the space for agency becomes restricted suffering deepens and it even takes a form of illnesses. That is in line with the theories of social suffering which emphasize the role of structural oppression in generating painful experiences (Frost \& Hoggett, 2008). However, the crucial question concerns the possibilities of the worker to develop transformative agency when suffering. Does suffering in work generate transformative actions or hinder them?

The narratives don't give a simple answer to that question. There seems to be dynamical and periodical processes between suffering, enduring and more transformative forms of agency during one's life-course or working life narrative. The different forms of agency overlap and rotate. Suffering can be seen as a dynamic concept mediating transformative agencies, small agency and resistance. Therefore, my second perception is that it is important to understand suffering not only as an experience, but also as a generative form and source of agency and power. However, developing the transformative agency while suffering seems to take many years, which contrasts to the idea of a flexible worker, who changes tasks and jobs fluently and whose only effort to take is learning new skills and competencies.

\section{Discussion and conclusions}

In this article, I took a closer look at the "labor market imperfections" that the economists have stated to hinder the fluent transition to the working life of future (Acemoglu \& Restrepo 2018) by studying experiences and agency of Finnish workers in change situations based on written working life narratives. I contributed to the literature of agency in working life changes that usually has focused either on transformative (positive) infirm agency (Tuominen \& Lehtonen, 2018) or on the workers resistance (Burawoy, 1979; Rafferty \& Jimmieson, 2017). My research task was to find out the varieties and connections of workers' agencies when they encounter changes at their workplaces. Better understanding of workers' agency is needed for developing practices that help people to learn and find the possibilities to act in the working life change situations.

The study shows, that in addition to transformative in-firm agency and resistance, there exists both transformative in-career agency and "small agency" in working life changes. The small agency takes a form of enduring suffering, getting illnesses or having a minimal influence in ones' own work. The study also revealed the meaning of (social) suffering in encountering the organizational changes and in forming individual agency. The suffering recipient of working life changes could be interpreted to be a fundamental source of the "labour market imperfections", about which the labor economists worry.

On the other hand, the results deepened the picture of enduring suffering as a form of (minor) agency in change situations by revealing it's connections to other, more powerful, forms of agency, namely transformative agency and resistance. I agree with Honkasalo (2008) in understanding enduring suffering as a small and ethical agency, but I propose that not to be the whole picture. In working life change situations, the small agency can generate resistance or transformative agency, although that is a slow process lasting for years. The life-course perspective, proposed by Eteläpelto and her colleagues (2013), helps to find out the interconnectedness, and dynamical, and changing nature of the varieties of agencies in working life changes.

This research have some practical applications, too. I found that there is a threat of losing one's agency (presence) in uncertain working life change situations, which generates suffering. Therefore, it is necessary to participate the workers to development 
processes as early as possible to make a space for their agency (see also Kalliola, Heiskanen \& Kivimäki, 2019). There might be a need for counselling practices, too. Interesting further question would be, if the participative development process or an individual counselling process could form the space needed for reflection and agency to develop.

The most notable limitation of this study is that it is based on retrospective qualitative research concerning only 48 working life narratives of Finnish people, mostly women. Qualitative and quantitative studies of the theme in Finland and in other countries are needed. Further research could consider closer the connections between the different kinds of agencies and the forms of small agency in varying contexts and countries, and the meaning of them with respect to learning. The life-course perspective could also be applied more profoundly to research the dynamics and connections between the varieties of agencies during different life phases.

\section{References}

Acemoglu, D., \& Restrepo, P. (2018). Artificial intelligence, automation and work. National Bureau of Economic Research. Working Paper No. 24196. doi:10.3386/w24196

Ackroyd, S. (2013). Organizational Misbehavior. Retrieved March 5, 2019, from https://doi.org/10.1002/9781405165518.wbeoso040

Biasin, C., \& Evans, K. (2019). Agency, identity and learning at turning points in women's lives: A comparative UK-Italian analysis. European Journal for Research on the Education and Learning of Adults, 10(1), 47-63. doi:10.3384/rela2000-7426.RELA915

Boram, D. (2018). An Affect-Based Model of Recipients' Responses to Organizational Change Events. Academy of Management Review, 43(1), 65-86. doi:10.5465/amr.2014.0335

Braverman, H. (1974). Labour and Monopoly Capital. The Degradation of Work in the Twentieth Century. New York, USA: Monthly Review Press.

Burawoy, M. (1979). Manufacturing Consent. Changes in the Labour Process under Monopoly Capitalism. Chicago, USA: The University of Chicago Press.

Burawoy, M. (1985). The Politics of Production. Factory Regimes Under Capitalism and Socialism. London, UK: Verso.

Edwards, R. (1979). Contested Terrain. The transformation of the workplace in the twentieth century. London: Heinemann.

Eteläpelto, A., Vähäsantanen, K., Hökkä, P., \& Paloniemi, S. (2013). What is agency? Conceptualizing professional agency at work. Educational Research Review, 10, 45-65. Retrieved February 20, 2019, from https://doi.org/10.1016/j.edurev.2013.05.001

Frey, C. B., \& Osborne, M. A. (2013). The future of employment: How susceptible are jobs to computerization? Retrieved February 15, 2019, from https://www.oxfordmartin.ox.ac.uk/downloads/academic/The_Future_of_Employment.pdf

Frost, L., \& Hoggett, P. (2008). Human agency and social suffering. $\bar{C}$ ritical Social Policy Ltd, 28(4), 438-460. doi:10.1177/0261018308095279

Graneheim, U. H., Lindgren, B-M., \& Lundman, B. (2017). Methodogical challenges in qualitative content analysis: A discussion paper. Nurse Education Today, 56, 29-34.

Gratton, L. (2011). The Shift. The future of work is already here. London, UK: Collins.

Harman, K. (2014). The multiple reals of workplace learning. European Journal for Research on the Education and Learning of Adults, 5(1), 51-66. doi:10.3384/rela.2000-7426.rela9021

Honkasalo, M-L. (2008). Enduring as a mode of living with uncertainty. Health, Risk \& Society, 10(5), 491-50. doi:10.1080/1369857080240870

Honkasalo, M-L. (2009). Grips and ties: Agency, Uncertainty, and the Problem of Suffering in North Karelia. Medical Anthropology Quarterly, 23(1), 51-69. doi:10.1111/j.1548-1387.2009.01037.x

Hyvärinen, M., Hatavara, M., \& Hydén, L-C. (2013). The Travelling Concepts of Narrative. Amsterdam, The Netherlands: John Benjamins.

Järvensivu, A. (2007). Työprosessitieto - avain monitaitoisuuteen. Tampere: Tampere University Press. Järvensivu, A. (2014). Tarinoita suomalaisesta työelämästä. Tampere: Finnish Institute of Occupational Health. 
Järvensivu, A. (2016). Hiljaisuudesta kertomuksiksi: työelämän sosiaalisesta kärsimyksestä. Sosiaalilääketieteellinen Aikakauslehti, 53(3), 178-188.

Järvensivu, A., \& Koski, P. (2012). Combating learning. Journal of Workplace Learning, 24(1), 5-18. doi: $10.1108 / 13665621211191078$

Kalliola, S., Heiskanen, T., Kivimäki, R. (2019). What Works in Democratic Dialogue? Social Sciences, 8(3), 101. Retrieved April 2, 2019 from https://doi.org/10.3390/socsci8030101

Nedelkoska, L., \& G. Quintini (2018). Automation, skills use and training. OECD Social, Employment and Migration Working Papers, No. 202. Paris, France: OECD Publishing. doi:10.1787/2e2f4eeaen

Rafferty, A. E., \& Jimmieson, N. L. (2017). Subjective Perceptions of Organizational Change and Employee Resistance to Change: Direct and Mediated Relationships with Employee Well-being. British Journal of Management, 28(2), 248-264. doi:10.1111/1467-8551.12200

Renault, E. (2010). A Critical Theory of Social Suffering. Critical Horizons, 11(2), 221-241. doi:10.1558/crit.v.11i2.221

Tuominen, T. M., \& Lehtonen, M. H. (2018). The Emergence of Transformative Agency in Professional Work. Organization Studies, 39(11), 1601-1624. doi:10.1177/0170840617717093

Wainwright, D. \& Calnan, M. (2002) Work Stress: The Making of a Modern Epidemic. London, UK: Open University Press.

World Economic Forum. (2018). The Future of Jobs Report 2018. Centre for the New Economy and Society. https://www.weforum.org/reports/the-future-of-jobs-report-2018 